\title{
Passenger Preferences in Rail Transport in Poland as Regards Travelling Time and Cost
}

\author{
Grażyna Rosa
}

check for

updates

Citation: Rosa, G. Passenger Preferences in Rail Transport in Poland as Regards Travelling Time and Cost. Sustainability 2021, 13, 4737 https://doi.org/10.3390/su13094737

Academic Editor: Adam Torok

Received: 5 March 2021

Accepted: 21 April 2021

Published: 23 April 2021

Publisher's Note: MDPI stays neutral with regard to jurisdictional claims in published maps and institutional affiliations.

Copyright: (C) 2021 by the author. Licensee MDPI, Basel, Switzerland. This article is an open access article distributed under the terms and conditions of the Creative Commons Attribution (CC BY) license (https:/ / creativecommons.org/licenses/by/ $4.0 /)$.
Institute of Spatial Management and Socio-Economic Geography, University of Szczecin, 70-453 Szczecin, Poland; grazyna.rosa@usz.edu.pl

\begin{abstract}
The paper includes an analysis of passengers' preferences in the context of selected marketing activities conducted by leading railway companies operating in the passenger transport sector in Poland. Operators' offers are highly varied, which may make it difficult to find the benefits expected by the passenger. Basing on earlier research, the main categories covered by operators classic marketing activities include the time and cost of the journey, and, less frequently, safety and comfort. The purpose of the analysis was to find whether the categories of time and price (cost categories) applied in most of the marketing activities, used for development of the operator's offer, corresponded with contemporary passengers' preferences. The conclusions are based on the results of primary research conducted on a random-quota sample of 1012 passengers. Research resultsmajor factors determining preferences among long-distance passengers included trip duration and favorable departure hours, whereas the price was not a major issue. The importance of price increased with the age of respondents. Moreover, on short-distance routes, price and time were major factors depending on the domicile of respondents. The smaller the town, the more important these two factors were.
\end{abstract}

Keywords: passenger transport; passenger preferences; rail transport; marketing

\section{Introduction}

The possibilities of development of railway passenger transport in Poland are connected with an analysis of behaviors of individuals purchasing such services, which leads to answering the questions of how decisions are made by passengers, what factors influence those decisions, what their needs and preferences are. Transport needs of residents, connected with organization of social life, are determined by the situation of workplaces, education institutions, retail outlets, leisure locations, institutions of culture and science, as well as public administration bodies. People's movements may also be connected with maintaining interpersonal relations [1]. The behaviors of passengers in the market of services, including transport services, may be defined as any observable response to impulses from the surroundings or the total of reactions and attitudes towards them. These are focused on direct satisfaction of consumption related needs, as a result of purchasing decisions made. Passengers' behaviors are related to social and economic factors typical of a respective population, such as: Age, education, possession of a car, household size, and income [2]. In passenger transport, the essential factors which influence the demand include: Number of residents, distribution and concentration of settlement, level of regional economic development, the society's purchasing power, time devoted to various forms of activity, costs of using individual means of transport in relation to prices of services provided by public means of transport, importance of particular preferences determining the service offer quality $[3,4]$. "Consumers' behaviors are the effect of reactions to the above social, psychological, and economic conditions, and may be analyzed by way of observation of actual choices (quantitative indicators) and declarations regarding the way of behaving, aspirations, evaluations, opinions, and motives (qualitative indicators)" [5]. Passengers' behaviors are strictly connected with their preferences. 
The objective of the analysis is:

- To analyze what influence on decisions of passengers in passenger transport is exerted by the time and price, referred to by many authors, in short-distance journeys (municipal and suburban transport) and in long-distance journeys (between different agglomerations), and

- to obtain an answer to the question whether or not passengers analyze the time and costs of journeys on short and long distances in the context of their age and place of residence.

The application purpose of the study is to outline directions related to researching preferences of passenger of railway passenger transport services and to identify the possibilities related to development of railway passenger service offer.

The study was designed to verify the following statements:

- On short-distance routes, price and time and related factors are the most important.

- On short-distance routes, travelling time/convenient departure hours and related factors are the most important.

- On long-distance routes, price is the most important.

- On long-distance routes, travelling time/convenient departure hours are the most important.

It is also important to obtain answers to the following questions:

1. While facing a choice of individual transport (e.g., car, taxi, bicycle) and public transport (e.g., train, tram, bus) to commute to work/university, have you ever compared their costs?

2. While facing a choice of individual transport (e.g., car, taxi, bicycle) and public transport (e.g., train, tram, bus) to commute to work/university, have you ever compared travelling times?

3. While facing a choice of individual transport (e.g., car) and public (e.g., train, bus, airplane) for long-distance trips in Poland, have you ever compared their costs?

4. While facing a choice of individual transport (e.g., car) and public (e.g., train, bus, airplane) for long-distance trips in Poland, have you ever compared travelling times?

\section{Literature Review}

Passenger preferences are most often understood as subjective evaluations or a rating system underlying the choices made in the purchase process [6], which influence passenger behavior. Passenger preferences result from the passenger's desire to satisfy his needs and choose those services from among those available on the market that meet his expectations [7-9]. Preferences supported by purchasing power become demand [10]. Beliefs arise when a passenger chooses a service from among the available options, which involves preferring one mode of transport or operator over others [11-13]. Beliefs (preferences) can be formed by passengers based on their opinions, knowledge, emotions or belief $[14,15]$. They are a reflection of what the passenger thinks about a particular service. They are subjective feelings that reflect their preferences. It is worth remembering that passengers are constantly expanding their knowledge of the market, and consequently their preferences are also changing. The activities of competitors, especially in terms of increasing passenger value, cause that under their influence even loyal passengers may consider changing their current service provider [16,17].

Many authors of earlier publications, those from the beginning of this century, emphasize in their works that passengers on the Polish passenger transport market focus on reliability and availability of services [18-23]. This statement refers to the low level of basic services offered by the Polish State Railways, a monopolistic carrier, and describes the state of services before the 1989 transition and in the early post-transition period. However, as a result of the evolution of the transport services market and increased competition, there have been significant changes in passenger expectations, resulting in the emergence of new preferences in addition to traditional expectations [24,25]. The importance of standard 
services is decreasing. The role of knowledge, cooperation skills, entrepreneurship and innovation is increasing [26-30]. Contemporary authors observe changes in passenger behavior and new directions in the formation of their preferences [31]. It is necessary to constantly monitor these changes and flexibly adapt to them [32].

Passenger preferences on the Polish railroad market are still an insufficiently researched topic in the literature [13,33-36]. There are examples of studies classifying passengers' preferences in different ways $[13,33,36]$, but referring to costs, travel time, and various other categories. Passenger preferences have also been studied by many authors worldwide, for example: O. Froidh, C. Bystrom [37], and S. Tsafarakis et al. [38]-MUSA, or multi-criteria satisfaction analysis, can be used to measure passenger satisfaction from different angles and to make improvements in many areas, and J. Paha et al. [39], who see the habits and emotional attitude of passengers towards the operator.

The most frequently mentioned preference categories in the literature, include [31-33,40-47]:

1. Cost (ticket prices, price promotions) $[8,13,34-36]$,

2. Time (short waiting time, short travel time, convenient connection times, connection frequency) $[13,33,35,36]$,

3. Travel comfort convenience, which consists of: $[13,34,35]$

- Ticket purchase and related traveler experience [31,32],

- personal security, covering all stages of the journey [30],

- multi-aspect quality of transport services, concerning: Stations, platforms, vehicles, service on the train, travel conditions [33,41,43-49],

- emotional attitude of a passenger to the railroad [39,50],

- accessibility of railroads for travelers with disabilities [36],

- quality of service provided by railroad staff before, during and after the journey $[12,26-30,41,42]$, and

- passenger information system provided through all available channels [40].

A review of the literature and available research indicates that passengers make mode choice decisions under conditions of uncertainty [50]. The variables known to the passenger at the time of decision-making are usually the cost of travel, departure time, and possible travel time. Researchers emphasize that passenger decisions are influenced by the passenger's routine and habitual transportation-related behaviors based on their experiences [39]. Many authors emphasize that the preferences developed on this basis tend to focus on time and price (travel cost) and their components [8].

Passengers are increasingly demanding in terms of travel comfort, and indeed the whole process: The partner approach of the operator, the quality of the services offered, safety, the provision of ongoing passenger service information, and often even a comprehensive logistical service on a national and international scale. The importance of innovations in transport services, technology, and passenger relations is recognized [26-30]. Due to the availability of online services and information, the "digital traveler", has constantly increasing demands and expects personalized service [12]. Research conducted by many Polish and foreign authors indicates that passengers evaluate which offer in their opinionregardless of motives-will provide them with the highest perceived value and choose this offer. Whether or not the offer meets their expectations affects passenger satisfaction and the likelihood of buying the service again $[48,49]$. There are studies on mode choice decision making that can predict what risks passengers are willing to take when given a choice among different modes of transportation [50,51].

Correctly identifying passenger preferences that shape purchasing behavior often has a decisive impact on the market position of companies. This is due to the fact that the passenger is influenced by many factors of a subjective nature, which are difficult to specify because they refer to feelings and experiences that the passenger acquires during his life $[36,38]$. Sensations of this type are referred to as intrinsic preferences, which reflect the passenger's preferences. Passenger preference studies can be conducted on the basis of historical observations as well as data describing passenger intentions included in preference analysis methods. They refer to passengers' declared market behavior. With 
this assumption, the primary source of information is in the form of data collected through direct and indirect surveys thus recording passenger purchase preferences [17].

\section{Materials and Methods}

The analysis was performed using the CAWI method (Computer Assisted Web Interviews) (on a representative sample of $n=1012$ adult residents of Poland, aged from 25 to 60. The sample was controlled in terms of social and demographic variables, gender, age, and size of the town or city of residence.

In this article the age of passengers and place of residence were assumed for analysis. Their choice was determined by the analysis of the offer of the main operators in Poland, both in the rail and bus markets, in which the main incentive factor is the differentiation of services and prices for different segments of travelers, distinguished by age and distance of travel, as presented in the studies of Kos et al. [33] and the Railway Transport Office [40,52].

A study of purchasing decisions in relation to age can be found in the work of AwadNúñez et al. [53], in which the authors recognize the specificity of decision-making by young people, over 19 years of age. The importance of the age of travelers in the ways of decision making is also recognized by the authors Kothari, et al. [54]

Place of residence is an important variable as ticket pricing and many fare promotions are related to the distance and frequency of traveler's transportation [55]. Available research shows that travelers in Poland most often use rail transportation to commute to work [52]. Market researchers also recognize that competition in the passenger transport market increases with the size of the place of residence [36,52].

In case of a city with an industrial character the following situations may occur:

- High population density, close distances to work, intensive use of public transport, reduced use of individual transport.

- Spatial development of the city. Firstly, suburbs and suburban settlements expand along the railroad or road line, and then they are absorbed into the city-the distance to work increases-the use of railroad, car and individual transport.

- Excessive concentration of population and economic activity in the city itself gradually relieved by the relocation of residential and industrial functions to the city outskirts and even beyond-development of the suburban zone-utilizing rail, road, and individual transport.

Authors conducting research in the field of industrial cities, come to the conclusion that the indicator of industrial development does not show correlation with the number of residents, and the dynamics of change of those employed in the industrial sector-with the dynamics of population change [56], so there is no need for special treatment in the study of travel preferences. Fröidh O., Byström C. [37] "presents the findings of a study conducted to examine the newly deregulated market for train journeys and travelers' preferences as regards two different train operators and several service levels. A stated choice study was conducted among existing train travelers, and a multinomial logit model structure was applied in the study to examine the benefits derived from choosing a specific train. The models are estimated on segments of the train travelers in order to investigate how the preferences differ among different categories of travelers. In addition, more questions were asked on the supply to provide better understanding of the effects. The findings show that fares and short travel times are important factors for interregional passengers (more than $100 \mathrm{~km}$ ) when they choose an operator on the WCL. Frequency of departures is also important but seems to be less significant when respondents are asked about suitable departure times. However, the importance of traveling time and comfort increases with longer journeys, which gives advantages for the commercial operator (SJ) over Öresund trains. Moreover, well-known SJ was ranked higher than Öresund trains by all passengers except a group of particularly price-sensitive travelers".

The survey was planned in January 2020, the research company was selected in a competition by the University of Szczecin. The survey was conducted in April 2020, when a pandemic state was declared in Poland and movement was banned for no apparent reason. 
Only online contact remained with the respondents. The research company has very good references. It guarantees the reliability and credibility of the results.

On the basis of data obtained from the Central Statistical Office, the demographic structure of people aged 25-60 in Poland was determined in terms of gender and place of residence. Then, using the formula for the necessary sample size, assuming the previously given level of significance and the maximum acceptable estimation error, the target sample size was determined at the level of 1067 respondents. Taking into account the earlier information about the structure of the surveyed population in terms of gender and place of residence, the preferred number of questionnaires that should be addressed to a specific group of respondents was determined. This allowed, in a certain way, to control the research sample due to its structure. The research questionnaire consisted of two main parts: A questionnaire and a survey. In the first part, respondents were asked to fill in a questionnaire, in which they provided their age and place of residence. This allowed us to automatically control whether a sufficient number of questionnaires had already been obtained from the given group of respondents. If there were not enough questionnaires, the respondent was redirected to the second part of the survey. If, on the other hand, it appeared that a sufficient number had already been obtained from a given group of respondents, the respondent in question ended participation in the survey at that point.

The Table 1 presents information on the actual structure of the population aged 25-60 in Poland at the end of 2019 in terms of gender and place of residence, as well as information on the number of surveys directed to particular groups of respondents.

Table 1. The information on the number of surveys directed to particular groups of respondents (source: Own analysis, $n=1067$ ).

\begin{tabular}{|c|c|c|c|c|}
\hline Age Group. & Sex & Location & $\begin{array}{c}\% \text { of the } \\
\text { Study Group }\end{array}$ & $\begin{array}{c}\text { Number of } \\
\text { Surveys }\end{array}$ \\
\hline \multirow{4}{*}{$25-34$} & & In cities & $8.21 \%$ & 88 \\
\hline & Men & In the countryside & $6.14 \%$ & 65 \\
\hline & & In cities & $8.18 \%$ & 87 \\
\hline & Women & In the countryside & $5.71 \%$ & 61 \\
\hline \multirow{4}{*}{ 35-44 } & & In cities & $10.05 \%$ & 107 \\
\hline & Men & In the countryside & $6.42 \%$ & 68 \\
\hline & & In cities & $10.07 \%$ & 107 \\
\hline & Women & In the countryside & $6.05 \%$ & 65 \\
\hline \multirow{4}{*}{$45-54$} & & In cities & $7.24 \%$ & 77 \\
\hline & Men & In the countryside & $5.40 \%$ & 58 \\
\hline & & In cities & $7.56 \%$ & 81 \\
\hline & Women & In the countryside & $5.12 \%$ & 55 \\
\hline \multirow{4}{*}{$55-60$} & & In cities & $3.90 \%$ & 42 \\
\hline & Men & In the countryside & $3.38 \%$ & 36 \\
\hline & & In cities & $4.16 \%$ & 44 \\
\hline & Women & In the countryside & $2.42 \%$ & 26 \\
\hline & Time & & $100.00 \%$ & 1067 \\
\hline
\end{tabular}

The survey focused on distinguishing sex, age, and domicile following similar surveys [36]. A decision was made to start with the study of these basic parameters and their possible relation with research statements. Other parameters will be covered by further studies based on our own qualitative analysis of passenger preferences and physical accessibility of operators in smaller and larger towns. In smaller towns, the accessibility of a rail operator is usually limited comparing to larger ones and a trip takes longer. This influences behavior and preferences among passengers. In mid-size and large cities, the accessibility of operators is larger, rail operators compete with other modes, trips are shorter, and this also influences passenger behavior and preferences [13]. 
The random-quota selection of the sample used for the survey, connected with specific characteristics of analysis carried out with the CAWI method, did not enable application of broad statistical inference and, therefore, a major part of the quantitative analysis came down to indication of frequency.

Still, the size of research sample, which included over 1000 respondents, ensured high objective representativeness for the analyzed general population.

To increase relevance of quantitative data analysis, occurrence of statistical significance level related to interdependencies between variables was analyzed. To do so, the tests used included the Kruskal-Wallis tests, U Mann-Whitney test, chi square test and Spearman's rank correlation coefficient. Considering the sample selection referred to above, outcomes of the tests and coefficients should not be applied to a broader group than research participants.

\section{Research Sample Characterization}

Characterization of the research sample may be performed with respect to gender, age and size of the town or city where the respondent lives.

By gender: women-53.6\%, men-46.4\%.

By age: $25-29$ years $-14.7 \%$, 30-34 years $-18.2 \%$, 35-39 years- $15.7 \%$, $40-44$ years $-14.6 \%, 45-49$ years $-12.2 \%, 50-54$ years $-12.2 \%$, $55-59$ years $-10.4 \%$, above 59 years $-2.1 \%$.

Table 2 present characteristics of respondents by age, whereas Figure 1 presents characteristics of respondents by place of residence.

Table 2. Age of respondents-descriptive statistics (source: Own analysis, $n=1012$ ).

\begin{tabular}{ccccc}
\hline Variable & Average & Minimum & Maximum & $\begin{array}{c}\text { Standard } \\
\text { Deviation }\end{array}$ \\
\hline age (in years) & 40.87 & 25.00 & 60.00 & 10.00 \\
\hline
\end{tabular}

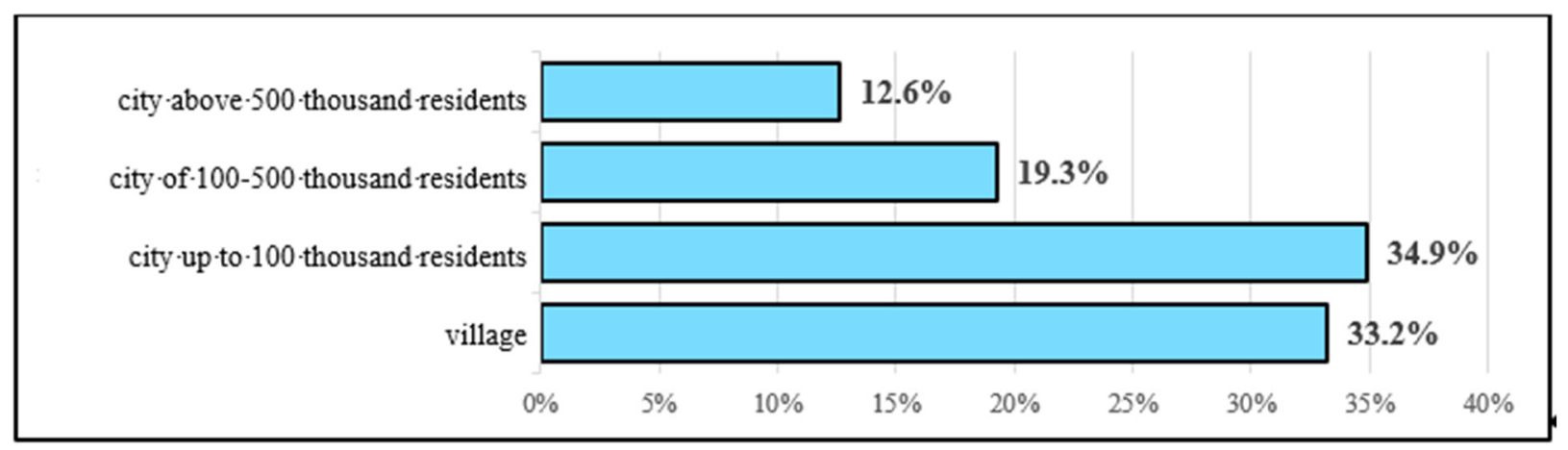

Figure 1. Breakdown of respondents by place of residence (source: Own analysis, $n=1012$ ).

The age structure of passengers in Poland is similar to the research, considering that sampling was random and quota based. It is difficult to use the CAWI to interview elderly Poles since they rarely use electronic devices and are reluctant to participate in surveys. Moreover, these people do not travel too often.

This has been confirmed in the study by the Rail Transport Office [36]. "The survey was carried out from 17 April to 15 July 2019. It involved an interactive questionnaire available at the website of the Rail Transport Office (www.utk.gov.pl/ankieta, accessed on 19 March 2021). It was a qualitative survey. The questionnaire consisted of 50 questions, of which 36 were closed questions. Answers to these questions were selected from a list indicating the level of concurrence with a research statement. The other 14 questions were open and respondents were unrestricted to provide their answers. Apart from subject related questions, the questionnaire contained basic information about respondents to determine their demographics, i.e., sex, age group, and their entitlement to ticket discounts. 
The questionnaires were filled out by 5646 respondents, of which $58.2 \%$ were men and $41.8 \%$ women. As many as $93 \%$ of respondents were people at their working age, i.e., 18-60. The largest age group consisted of people at the age of $24-39(49 \%)$, whereas the smallest people $60+(1.5 \%, n=82)$.

The majority of respondents were people travelling by train every day (56.6\%). Commuters travelling to work/school accounted for $71.8 \%$, and it was significant factor while analyzing survey findings. On the one hand, it is the most loyal group, members of which can indicate valuable recurrent factors that determine the quality of travelling, while on the other, these people are used to certain standards. These standards are considered the "normal" by a given operator, railway line, station, etc."

\section{Research Results-Impact of Age and Place of Residence of the Residents onto Evaluation of Specified Theses Related to Passenger Transport}

The research results will be presented in the following order:

1. passenger evaluation of specific transportation-related theses (Table 3),

2. the influence of the respondents' age on the evaluation of specific theses related to passenger transport (Tables 4,6 and 8 ),

3. the influence of the respondents' place of residence on the evaluation of specific theses related to passenger transport (Tables 5, 7 and 9).

Table 3. Evaluation of specified theses related to transport (source: Own analysis, $n=1012$ ).

\begin{tabular}{|c|c|c|c|c|}
\hline \multirow{2}{*}{ Thesis: } & \multicolumn{4}{|c|}{ Evaluation: } \\
\hline & Definitely Yes & Rather Yes & Rather No & Definitely No \\
\hline $\begin{array}{l}\text { Efficiently operating municipal transport } \\
\text { influences growth in the number of } \\
\text { passengers at the expense of } \\
\text { individual transport. }\end{array}$ & $27.2 \%$ & $56.3 \%$ & $15.4 \%$ & $1.1 \%$ \\
\hline $\begin{array}{c}\text { Railway transport enables quicker journeys } \\
\text { than individual transport in } \\
\text { regional transport. }\end{array}$ & $16.9 \%$ & $52.3 \%$ & $27.1 \%$ & $3.7 \%$ \\
\hline $\begin{array}{l}\text { Frequent changes in train timetables are an } \\
\text { important factor underlying selection of } \\
\text { alternative means of transport. }\end{array}$ & $15.2 \%$ & $55.9 \%$ & $25.7 \%$ & $3.2 \%$ \\
\hline $\begin{array}{l}\text { High costs of travelling by individual (car) } \\
\text { transport result in selecting railway transport } \\
\text { in regional and agglomeration transport. }\end{array}$ & $17.5 \%$ & $57.0 \%$ & $22.4 \%$ & $3.1 \%$ \\
\hline $\begin{array}{l}\text { The phenomenon of congestion (traffic jams) } \\
\text { and absence of or high parking fees in cities } \\
\text { result in choosing railway transport for } \\
\text { commuting to work/school. }\end{array}$ & $19.6 \%$ & $56.2 \%$ & $20.8 \%$ & $3.4 \%$ \\
\hline $\begin{array}{l}\text { The phenomenon of congestion (traffic jams) } \\
\text { and absence of or high parking fees in cities } \\
\text { result in choosing public municipal transport. }\end{array}$ & $22.2 \%$ & $54.4 \%$ & $20.2 \%$ & $3.2 \%$ \\
\hline $\begin{array}{l}\text { When able to select individual (e.g., car, taxi, } \\
\text { bicycle) or public (train, tram, bus) transport } \\
\text { for a journey to work/school, the respondent } \\
\text { performs a comparison of costs. }\end{array}$ & $20.5 \%$ & $54.8 \%$ & $21.4 \%$ & $3.3 \%$ \\
\hline
\end{tabular}


Table 3. Cont.

\begin{tabular}{|c|c|c|c|c|}
\hline \multirow{2}{*}{ Thesis: } & \multicolumn{4}{|c|}{ Evaluation: } \\
\hline & Definitely Yes & Rather Yes & Rather No & Definitely No \\
\hline $\begin{array}{l}\text { When able to select individual (e.g., car, taxi, } \\
\text { bicycle) or public (train, tram, bus) transport } \\
\text { for a journey to work/school, the respondent } \\
\text { performs a comparison of the time of journey. }\end{array}$ & $22.3 \%$ & $54.0 \%$ & $20.3 \%$ & $3.4 \%$ \\
\hline $\begin{array}{l}\text { When able to select individual (e.g., car) or } \\
\text { public (train, bus, airplane) transport for a } \\
\text { long-distance journey in Poland, the } \\
\text { respondent performs a comparison of costs. }\end{array}$ & $22.1 \%$ & $55.5 \%$ & $19.4 \%$ & $3.0 \%$ \\
\hline $\begin{array}{l}\text { When able to select individual (e.g., car) or } \\
\text { public (train, bus, airplane) transport for a } \\
\text { long-distance journey in Poland, the } \\
\text { respondent performs a comparison of the } \\
\text { time of journey. }\end{array}$ & $24.2 \%$ & $55.2 \%$ & $17.9 \%$ & $2.7 \%$ \\
\hline $\begin{array}{l}\text { The price is the most important factor in } \\
\text { long-distance journeys. }\end{array}$ & $16.8 \%$ & $51.2 \%$ & $28.2 \%$ & $3.8 \%$ \\
\hline $\begin{array}{l}\text { The time/convenient journey hours are the } \\
\text { most important factor in } \\
\text { long-distance journeys. }\end{array}$ & $27.0 \%$ & $58.7 \%$ & $12.3 \%$ & $2.0 \%$ \\
\hline
\end{tabular}

Table 4. Respondents' opinion on impact of efficient operation of municipal transport onto growth in the number of passengers at the expense of individual transport vs. their age (source: Own analysis, $n=1012$ ).

\begin{tabular}{|c|c|c|c|}
\hline \multirow{2}{*}{$\begin{array}{l}\text { Efficiently Operating Municipal Transport Influences Growth in the } \\
\text { Number of Passengers at the Expense of Individual Transport. }\end{array}$} & \multirow{2}{*}{$n$} & \multicolumn{2}{|c|}{ Age (in years) } \\
\hline & & Average & Standard Deviation \\
\hline definitely yes & 275 & 41.78 & 10.53 \\
\hline rather yes & 570 & 41.01 & 9.96 \\
\hline rather no & 156 & 38.76 & 9.05 \\
\hline definitely no & 11 & 41.00 & 8.51 \\
\hline total & 1012 & 40.87 & 10.00 \\
\hline \multicolumn{2}{|l|}{ Statistical significance: } & \multicolumn{2}{|c|}{$\mathrm{r}_{\mathrm{S}}=0.076697, p=0.014669$} \\
\hline
\end{tabular}

Table 5. Respondents' opinion on the possibility of quicker journeys by railway transport than by individual transport in regional transport vs. place of residence (source: Own analysis, $n=1012$ ).

\begin{tabular}{|c|c|c|c|c|c|c|}
\hline \multirow{2}{*}{\multicolumn{2}{|c|}{$\begin{array}{c}\text { Railway Transport Enables } \\
\text { Quicker Journeys Than } \\
\text { Individual Transport in } \\
\text { Regional Transport. }\end{array}$}} & \multicolumn{4}{|c|}{ Size of Town or City } & \multirow[b]{2}{*}{ Total } \\
\hline & & Village & $\begin{array}{l}\text { City Up to } 100 \\
\text { Thousand } \\
\text { Residents }\end{array}$ & $\begin{array}{l}\text { City of } 100-500 \\
\text { Thousand } \\
\text { Residents }\end{array}$ & $\begin{array}{l}\text { City Above } 500 \\
\text { Thousand } \\
\text { Residents }\end{array}$ & \\
\hline & $\mathrm{n}$ & 69 & 57 & 28 & 17 & 171 \\
\hline Definitely yes & $\%$ & $20.5 \%$ & $16.2 \%$ & $14.3 \%$ & $13.3 \%$ & $16.9 \%$ \\
\hline \multirow{2}{*}{ Rather yes } & $\mathrm{n}$ & 173 & 190 & 98 & 68 & 529 \\
\hline & $\%$ & $51.5 \%$ & $53.9 \%$ & $50.3 \%$ & $53.1 \%$ & $52.3 \%$ \\
\hline \multirow[b]{2}{*}{ Rather no } & $\mathrm{n}$ & 81 & 99 & 56 & 38 & 274 \\
\hline & $\%$ & $24.1 \%$ & $28.0 \%$ & $28.7 \%$ & $29.7 \%$ & $27.1 \%$ \\
\hline \multirow{2}{*}{ Definitely no } & $\mathrm{n}$ & 13 & 7 & 13 & 5 & 38 \\
\hline & $\%$ & $3.9 \%$ & $2.0 \%$ & $6.7 \%$ & $3.9 \%$ & $3.7 \%$ \\
\hline \multirow{2}{*}{ Total } & $\mathrm{n}$ & 336 & 353 & 195 & 128 & 1012 \\
\hline & $\%$ & $100.0 \%$ & $100.0 \%$ & $100.0 \%$ & $100.0 \%$ & $100.0 \%$ \\
\hline \multicolumn{2}{|c|}{ Statistical significance: } & \multicolumn{4}{|c|}{$\mathrm{r}_{\mathrm{S}}=-0.077232, p=0.013989$} & \\
\hline
\end{tabular}


Table 6. Respondents' opinion on the possibility of quicker journeys by railway transport than by individual transport in regional transport vs. their age (source: Own analysis, $n=1012$ ).

\begin{tabular}{|c|c|c|c|}
\hline \multirow{2}{*}{$\begin{array}{c}\text { Railway Transport Enables Quicker Journeys Than Individual } \\
\text { Transport in Regional Transport. }\end{array}$} & \multirow{2}{*}{$n$} & \multicolumn{2}{|c|}{ Age (in Years) } \\
\hline & & Average & Standard Deviation \\
\hline definitely yes & 171 & 42.61 & 10.26 \\
\hline rather yes & 529 & 40.78 & 10.01 \\
\hline rather no & 274 & 40.01 & 9.62 \\
\hline definitely no & 38 & 40.58 & 10.74 \\
\hline total & 1012 & 40.87 & 10.00 \\
\hline \multicolumn{2}{|l|}{ Statistical significance: } & \multicolumn{2}{|c|}{$\mathrm{r}_{\mathrm{S}}=0.073313, p=0.019675$} \\
\hline
\end{tabular}

Table 7. Comparison of the costs of individual and public transport to work/school by residents vs. their place of residence (source: Own analysis, $n=1012$ ).

\begin{tabular}{|c|c|c|c|c|c|c|}
\hline \multirow{2}{*}{\multicolumn{2}{|c|}{$\begin{array}{l}\text { When Able to Select Individual (e.g., Car, } \\
\text { Taxi, Bicycle) or Public (Train, Tram, Bus) } \\
\text { Transport for a Journey to Work/School, the } \\
\text { Respondent Performs a Comparison } \\
\text { of Costs. }\end{array}$}} & \multicolumn{4}{|c|}{ Size of Town or City } & \multirow[b]{2}{*}{ Total } \\
\hline & & Village & $\begin{array}{l}\text { City Up to } 100 \\
\text { Thousand } \\
\text { Residents } \\
\end{array}$ & $\begin{array}{c}\text { City of 100-500 } \\
\text { Thousand } \\
\text { Residents }\end{array}$ & $\begin{array}{l}\text { City Above } 500 \\
\text { Thousand } \\
\text { Residents }\end{array}$ & \\
\hline \multirow{2}{*}{ Definitely yes } & $n$ & 81 & 62 & 39 & 25 & 207 \\
\hline & $\%$ & $24.1 \%$ & $17.6 \%$ & $20.0 \%$ & $19.6 \%$ & $20.5 \%$ \\
\hline \multirow{2}{*}{ Rather yes } & $n$ & 182 & 206 & 99 & 68 & 555 \\
\hline & $\%$ & $54.1 \%$ & $58.4 \%$ & $50.8 \%$ & $53.1 \%$ & $54.8 \%$ \\
\hline \multirow{2}{*}{ Rather no } & $n$ & 63 & 76 & 47 & 31 & 217 \\
\hline & $\%$ & $18.8 \%$ & $21.5 \%$ & $24.1 \%$ & $24.2 \%$ & $21.4 \%$ \\
\hline \multirow{2}{*}{ Definitely no } & $n$ & 10 & 9 & 10 & 4 & 33 \\
\hline & $\%$ & $3.0 \%$ & $2.5 \%$ & $5.1 \%$ & $3.1 \%$ & $3.3 \%$ \\
\hline \multirow[b]{2}{*}{ Total } & $n$ & 336 & 353 & 195 & 128 & 1012 \\
\hline & $\%$ & $100.0 \%$ & $100.0 \%$ & $100.0 \%$ & $100.0 \%$ & $100.0 \%$ \\
\hline \multicolumn{2}{|c|}{ Statistical significance: } & \multicolumn{4}{|c|}{$\mathrm{r}_{\mathrm{S}}=-0.065587, p=0.036967$} & \\
\hline
\end{tabular}

Table 8. Comparison of costs of long-distance individual and public transport performed by respondents vs. their age. (source: Own analysis, $n=1012$ ).

\begin{tabular}{|c|c|c|c|}
\hline \multirow{2}{*}{$\begin{array}{l}\text { When Able to Select Individual (E.G. Car) or Public (Train, Bus, } \\
\text { Airplane) Transport for a Long-Distance Journey in Poland, the } \\
\text { Respondent Performs a Comparison of Costs. }\end{array}$} & \multirow{2}{*}{$n$} & \multicolumn{2}{|c|}{ Age (in Years) } \\
\hline & & Average & Standard Deviation \\
\hline definitely yes & 224 & 41.81 & 9.99 \\
\hline rather yes & 562 & 40.91 & 10.00 \\
\hline rather no & 196 & 39.78 & 9.87 \\
\hline definitely no & 30 & 40.37 & 10.68 \\
\hline total & 1012 & 40.87 & 10.00 \\
\hline \multicolumn{2}{|l|}{ Statistical significance: } & \multicolumn{2}{|c|}{$r_{\mathrm{S}}=0.065929, p=0.035991$} \\
\hline
\end{tabular}

Further analysis covered correlation of age and size of the town or city of residence with evaluation of the above theses and answers to the questions asked. Research did not demonstrate a connection of gender with evaluation of the above theses connected with passenger transport. 
Table 9. Comparison of the time of journey by individual and public transport to work/school by residents vs. their place of residence (source: Own analysis, $n=1012$ ).

\begin{tabular}{|c|c|c|c|c|c|c|}
\hline \multirow{2}{*}{\multicolumn{2}{|c|}{$\begin{array}{l}\text { When Able to Select Individual (e.g., Car, } \\
\text { Taxi, Bicycle) or Public (Train, Tram, Bus) } \\
\text { Transport for a Journey to Work/School, the } \\
\text { Respondent Performs a Comparison of the } \\
\text { Time of Journey. }\end{array}$}} & \multicolumn{4}{|c|}{ Size of Town or City } & \multirow[b]{2}{*}{ Total } \\
\hline & & Village & $\begin{array}{l}\text { City Up to } 100 \\
\text { Thousand } \\
\text { Residents } \\
\end{array}$ & $\begin{array}{c}\text { City of } 100-500 \\
\text { Thousand } \\
\text { Residents }\end{array}$ & $\begin{array}{c}\text { City Above } 500 \\
\text { Thousand } \\
\text { Residents }\end{array}$ & \\
\hline \multirow{2}{*}{ Definitely yes } & $n$ & 95 & 65 & 36 & 30 & 226 \\
\hline & $\%$ & $28.3 \%$ & $18.4 \%$ & $18.5 \%$ & $23.4 \%$ & $22.3 \%$ \\
\hline \multirow{2}{*}{ Rather yes } & $n$ & 173 & 206 & 107 & 60 & 546 \\
\hline & $\%$ & $51.5 \%$ & $58.4 \%$ & $54.9 \%$ & $46.9 \%$ & $54.0 \%$ \\
\hline \multirow{2}{*}{ Rather no } & $n$ & 56 & 71 & 45 & 33 & 205 \\
\hline & $\%$ & $16.7 \%$ & $20.1 \%$ & $23.0 \%$ & $25.8 \%$ & $20.3 \%$ \\
\hline \multirow{2}{*}{ Definitely no } & $n$ & 12 & 11 & 7 & 5 & 35 \\
\hline & $\%$ & $3.5 \%$ & $3.1 \%$ & $3.6 \%$ & $3.9 \%$ & $3.4 \%$ \\
\hline \multirow[b]{2}{*}{ Total } & $\mathrm{n}$ & 336 & 353 & 195 & 128 & 1012 \\
\hline & $\%$ & $100.0 \%$ & $100.0 \%$ & $100.0 \%$ & $100.0 \%$ & $100.0 \%$ \\
\hline \multicolumn{2}{|c|}{ Statistical significance: } & \multicolumn{5}{|c|}{$\mathrm{r}_{\mathrm{s}}=-0.088075, p=0.005050$} \\
\hline
\end{tabular}

(a) Influence of respondents' age onto evaluation of specified theses connected with passenger transport (Tables 4, 6 and 8)

The result of Spearman's rank correlation coefficient shows occurrence of a statistically significant $(p<0.05)$ dependence between the variables. Respondents' agreement with the specified thesis increases with age. Value of the coefficient shows that the correlation had a statistically weak impact.

Thanks to a high number of individuals covered by the research, the value of the coefficient can evidence even very subtle dependencies between variables. Thus, even though differences between average ages are very small, statistical significance was still demonstrated. A similar situation occurred in two more instances. The group of respondents who replied "definitely no" is not numerous here. Consequently, their result, although higher than in the next group, "does not violate" the linear dependence between variables.

Spearman's correlation coefficient failed to prove a statistically significant correlation $(p>0.05)$ between variables, such as respondents' age and opinions concerning:

- Frequent timetable changes and their decision to use alternative modes,

- $\quad$ high cost of travelling by individual cars and their decision to use rail transport on regional and intra-agglomeration routes,

- congestion and parking fees in cities and their decision to use rail transport when commuting to work/university,

- $\quad$ congestion and parking fees in cities and their decision to use public transport

- comparison between cost of individual and public transport when commuting to work/university,

- comparison between individual and public transport as regards time needed to commute to work/university,

- comparison between individual and public transport as regards time needed to travel on long distances,

- $\quad$ significance of price in long distance trips, and

- $\quad$ significance of time and favorable departure hours in long distance trips.

(b) Impact of the size of the town or city of residence of respondents onto evaluation of specified theses related to passenger transport

The result of Spearman's rank correlation coefficient shows occurrence of a statistically significant $(p<0.05)$ dependence between the variables. Respondents' agreement with 
the specified thesis decreases with increase in size of the place of residence. Value of the coefficient had a statistically weak impact.

The result of Spearman's rank correlation coefficient did not evidence existence of a statistically significant $(p>0.05)$ dependence between the variables with respect to:

$\rightarrow$ Respondents' opinion on the impact of efficient operation of municipal public transport onto growth in the number of passengers at the expense of individual transport vs. their place of residence.

$\rightarrow$ Respondents' opinion on the impact of frequent changes in train timetables on selection of alternative means of transport vs. their place of residence.

$\rightarrow$ Respondents' opinion on the impact of high costs of travelling by individual transport onto selecting railway transport in regional and agglomeration transport vs. their place of residence.

$\rightarrow$ Respondents' opinion on the impact of the phenomenon of congestion and parking fees in cities onto choosing railway transport for commuting to work/school vs. their place of residence.

$\rightarrow$ Respondents' opinion on the impact of the phenomenon of congestion and parking fees in cities result onto choosing public municipal transport vs. their place of residence.

$\rightarrow$ Comparisons of costs of long-distance journeys by individual and public transport vs. their place of residence.

$\rightarrow$ Comparisons of the time of long-distance journey by individual and public transport by respondents vs. their place of residence.

$\rightarrow$ Respondents' opinion on the importance of price in long-distance journeys vs. their place of residence.

$\rightarrow$ Respondents' opinion the importance of time and convenient hours in long-distance journeys vs. their place of residence.

\section{Discussion}

The share of railroad transport in passenger transport in Poland is small, about 3\%, the remaining $97 \%$ is served by car transport [57-59]. Taking this into account, travelers purchasing decisions regarding the choice of means, operators, and modes of transport should be analyzed very carefully [60].

The presented results of my research showed that as the age of the respondents increased, their agreement with the given theses increased:

1. Efficient public transport influences the increase in the number of passengers at the expense of individual transport.

2. Railway transport enables faster travel than individual transport in regional transport.

3. Having a choice of individual (e.g., car) or public (train, bus, plane) long-distance travel in Poland, I make a comparative analysis of costs.

Thus, the results of available secondary research are confirmed, in which the key factors of passengers' decision-making focus on efficiency, speed (short waiting time, short travel time, convenient service hours, service frequency), and optimal price $[13,52,60]$, and detailed analysis shows that the older the traveler, the more importance he/she attaches to the use of public transport and rail transport, comparing prices and costs. The results of research conducted by the Railway Transport Office indicate that passenger cars are used primarily for commuting to work, as well as for shopping and leisure activities. The main reasons indicated by travelers for choosing a personal car for commuting to work or school instead of public transport are the excessive distance to the nearest public transport stop/station/station and the lack of appropriate connections in the public transport timetable as well as the long travel time by public transport [52]. This was also confirmed by the results of the qualitative research I conducted and presented in recent publications [34,35], which showed that convenient connection times (the most important feature) are the most important for young travelers. Almost equally important respondents included: Ticket price, safety in the means of transport, duration of travel, number of 
connections, and the possibility to check connections on the Internet. This is also confirmed by recent studies by authors Kos et al. [33], Hlavatý Ližbetin [40] and the Railway Transport Office [36]. "The UTK studies were conducted in July 2019, i.e., still in conditions without disruptions caused by the pandemic, in the form of an interactive survey posted on the website of the Railway Transport Office. They were qualitative in nature. In addition to the factual questions, a brief respondent metric was prepared to collect basic demographic data, i.e., gender, age range, and any eligibility for discounted rail travel. In this study, a total of 5646 respondents completed the survey form, of which as many as $93 \%$ were of productive age, i.e., 18-60 years. The largest group in terms of age was made up of 24-39 years old $(49 \%)$. The fewest responses were given by those over 60 years of age-only $1.5 \%(n=82)$. This barrier also emerged in my research-older people use electronic devices little or not at all, and are reluctant to participate in online surveys.

However, in the current situation of widespread COVID-19 threat, this is the only way to conduct research. The results of the research can also be associated with general economic information-older people, who are not economically active, receive relatively low pensions in Poland, therefore they pay more attention to the costs of travel, have a lot of free time and this parameter is less important to them, they use private cars less often, because of their age, fearing for the safety of travel, preferring public transport. Both in the survey conducted by me and by UTK, the respondents turned out to be mostly people who travel by rail daily (56.6\%). Combined, those traveling to/from work and school/college accounted for $71.8 \%$ of respondents, which is important for analyzing the survey results. This is the group of the most loyal rail customers, who indicate many recurring factors that influence their evaluation of travel quality. On the other hand, these people are accustomed to certain standards, which they treat as "normality" characteristic for a particular carrier, railroad line, station, etc. The research has shown the importance of the second examined parameter-place of residence. Travelers from small towns, who use railroad transport to get to/from work and school/university, pay much more attention to both travel time and travel costs, because they are relatively higher in relation to work time or salary, than for residents of large cities, who live closer or travel shorter and cheaper, having a choice of alternative means of transport. UTK's research showed that respondents choose rail because they believe travel by this mode is advantageous due to attractive travel time, price, and comfort."

The results of my research indicated that as the size of the respondents' place of residence increased, the agreement with the given statements decreased:

1. Rail transportation provides faster travel than individual transportation on regional services.

2. When given the choice of individual (e.g., car, cab, bicycle) or public (train, streetcar, bus) travel to work/university I make a comparative analysis of costs.

3. When given the choice of individual (e.g., car, cab, bicycle) or public (train, streetcar, bus) travel to work/university, I make a comparative analysis of travel time.

A partial confirmation of the given statements can be found in the research of the Railway Transport Office [36]: “Travelers are particularly positive about the level of ticket prices in the regional segment, with a clear lack of acceptance for the fare prevailing on commercial (long-distance) trains" and in the work of Kos et al. [33]. However, I did not find in the available studies any direct reference to the influence of the place of residence of travelers on the perception of such formulated theses.

The main limitation of my research is the current situation of COVID 19 pandemic. Many people travel in private cars on city and regional transport for safety. Travel is limited and travelers are discouraged, nervous and scared. In this situation, the surveys conducted show travel preferences that are appropriate for the early stages of a pandemic and relate to government recommendations to stay home. Undoubtedly, this situation may have influenced travelers' responses. Another important limitation is the choice of the research method in the discussed conditions, which is not representative and the results are qualitative in nature. Even the selection of the research company was difficult because 
many researchers suddenly sought the support of specialized entities in online research. This slowed down the implementation of research and increased the prices for research services. It is also reasonable to believe that after the slowdown in travel, the preferences of travelers will also change. This will provide an opportunity to explore the gap between the period up to early 2020 and in the future.

\section{Conclusions}

The formulation of the policy recommendation on the operation of operators and the implementation of preferences in the railroad passenger transport market is closely related to the policies of the European Union [25,61,62].

In January 2021, the European Commission (EC) presented another, seventh report on the development of the railroad market. It shows that new prospects are opening up for rail transport because:

1. The EU emphasizes the issue of sustainability, and this means that rail transport is the preferred mode of transport that continuously reduces greenhouse gas and $\mathrm{CO}_{2}$ emissions. It will be supported by both financial and other measures.

2. Introduced at EU level by the 4th railroad package, open access and mandatory competitive tendering for public service contracts in the domestic passenger market. This means increased competition between passenger service operators, which may be reflected in a better matching of offers with passengers' preferences.

Next, the Commission will present an action plan to develop rail passenger transport.

This will include simplifying ticket sales to make rail transport even more attractive.

According to the survey findings,

1. PKP Intercity, a long-distance train service provider, should focus on promoting travelling time with the focus on the target groups of senior citizens and adjust messages to the target group while taking into consideration price, since the factor is particularly important.

2. POLREGIO, a short- and medium-distance operator, should concentrate their marketing on time, while taking into consideration price as yet another important factor determining passenger preferences, especially in cities where people have a range of alternative modes. The marketing activity should focus on senior citizens, since according to the study, price is an important factor underlying their decisions.

3. Operators may also pool their resources to establish joint offers to attract more passengers, as shown by the study. A joint offer by POLREGIO and PKP Intercity encompasses travelling time and cost.

4. In the view of research findings, operators can introduce new and innovative elements which optimize travelling time and price. These may include, for example, integration of tariffs within an agglomeration or a region. This area on the Polish market has not been sufficiently examined and described in the literature.

5. The innovative nature of marketing applies to the Polish market only, since some of the solutions have been successfully implemented on a larger scale in other countries.

6. Safety should also be promoted-rail remains one of the safest modes of transport. Travelling by car is almost 50 times riskier than travelling by train.

Funding: This research was funded by the program of the Minister of Science and Higher Education under the name "Regional Excellence Initiative" in the years 2019-2022; project number 001/RID/2018/19; the amount of financing PLN 10,684,000.00.

Institutional Review Board Statement: Not applicable.

Informed Consent Statement: Not applicable. 
Data Availability Statement: Data collection was carried out by Agencja Badawczo-Marketingowa FAST SOLUTIONS [FAST SOLUTIONS Research and Marketing Agency], Rzeszów, Poland (accessed on day month year) in days 10 March 2020-20 April 2020 Please refer to suggested Data Availability Statements in section "MDPI Research Data Policies" at https:/ /www.mdpi.com/ethics, accessed on 19 March 2021.

Conflicts of Interest: The author declares no conflict of interest.

\section{References}

1. Kos, B.; Krawczyk, G.; Tomanek, R. Modelowanie Mobilności w Miastach; Wydawnictwo Uniwersytetu Ekonomicznego w Katowicach: Katowice, Poland, 2018; p. 47.

2. De Witte, A.; Hollevoet, J.; Dobruskes, F.; Hubert, M.; Macharis, C. Linking modal choice to mobility: A comprehensive review. Transp. Res. Part A 2013, 49, 329-341.

3. Bartosiewicz, B.; Pielesiak, I. Spartial patterns of travel behaviour in Poland. Travel Behav. Soc. 2019, 15, 113-122. [CrossRef]

4. Zitrický, V.; Gašparík, J.; Pečený, L. The methodology of rating quality standards in the regional passenger transport. Transp. Probl. 2017, 10, 59-72. [CrossRef]

5. Kędzior, Z.; Karcz, K. Badania Marketingowe w Praktyce; PWE: Warszawa, Poland, 2007; p. 12.

6. Rybicka, A. Wybrane metody badań preferencji konsumentów. Pr. Nauk. Ae We Wrocławiuzarzadzanie I Mark. 2003, 978, 103-112.

7. Kieżel, E.; Smyczek, S. Zachowania Konsumentów; Oficyna Wolters Kluwer: Warszawa, Poland, 2015.

8. Cerna, L.; Zitricky, V.; Ponicky, J. Income and price elasticity of demand for transport services in rail passenger transport in the Slovak republic. In Proceedings of the 34th International Conference Mathematical Methods in Economics (MME 2016), Liberec, Czech Republic, 6-9 September 2016. Available online: http://mme2016.tul.cz/conferenceproceedings/mme2016_conference_ proceedings.pdf (accessed on 19 March 2021).

9. Szymańska, A. Metodyczne problemy badań preferencji konsumenckich. Zesz. Nauk. Ae W Krakowie 2007, 739, 1-18.

10. Armstrong, G.; Kotler, P.H. Marketing, GAB Media; Wydawnictwo Nieoczywiste: Piaseczno, Polska, 2016.

11. Ermagun, A.; Hajivosough, S.; Samimi, A.; Rashidi, T.H. A joint model for trip purpose and escorting patterns of disabled. Travel Behav. Soc. 2016, 3, 51-58. [CrossRef]

12. Nyurenberger, L.; Luchina, N.; Sewruikov, I.; Tikhomirova, G. “2GO” Format Innovative Technologies in Tourism: Augmented Reality E of Travelling. In Proceedings of the 42nd International Scientific Conference on Economic and Social Development, London, UK, 12-13 June 2019; pp. 318-320.

13. Badanie Satysfakcji Pasażerów Kolei. Ankieta_Pasażerska_Wersja_Finalna (7); UTK: Warszawa, Polska, 2020. Available online: file: // /C:/Users/Gra\%C5\%BCyna\%20Rosa/Downloads/ankieta_pasazerska_wersja_finalna\%20(7).pdf (accessed on 14 April 2021).

14. Kotler, P.; Kartajaya, H.; Setiawan, I. Marketing 3.0. Dobry Produkt? Zadowolony Klient? Spetniony Człowiek? MT Biznes: Warszawa, Poland, 2010.

15. Kotler, P.; Kartajaya, H.; Setiawan, I. Marketing 4.0. Era Cyfrowa; MT Biznes: Warszawa, Poland, 2017.

16. Gracz, L.; Ostrowska, I. Młodzi Nabywcy na e-Zakupach; Placet: Warszawa, Poland, 2014.

17. Ostrowska, I.; Rosa, G.; Tomaszewicz, A. Customer Preferences in Passenger Railway Transport. In Proceedings of the Economic and Social Development 44th International Scientific Conference, Split, Croatia, 19-20 September 2019.

18. Bąkowski, W.; Szewczuk, A. Strategie konkurowania na rynku transportowym. In Ogólnopolska Konferencja Naukowa, Ektra; Fundacja na rzecz Uniwersytetu Szczecińskiego: Szczecin, Poland, 2000.

19. Engelhardt, J. Transport Kolejowy. In Uwarunkowania Rozwoju Systemu Transportowego Polski; Liberadzki, B., Mindur, L., Eds.; Wydawnictwo Instytutu Technologii Eksploatacji-PIB: Warszawa, Poland, 2007.

20. Paprocki, W. Marketing Ustug Kolejowych; Kolejowa Oficyna Wydawnicza: Warszawa, Poland, 1996.

21. Wyszomirski, O. Rynek Przewozów Pasażerskich; Wydawnictwo Uniwersytetu Gdańskiego: Gdańsk, Poland, 1994.

22. Wyszomirski, O. Funkcjonowanie Rynku Komunikacji Miejskiej; Wydawnictwo Uniwersytetu Gdańskiego: Gdańsk, Poland, 1998.

23. Tomanek, R. Konkurencyjność Transportu Miejskiego; Prace Naukowe Akademii Ekonomicznej w Katowicach: Katowice, Poland, 2002.

24. Kłeczek, R.; Pluta-Olearnik, M.; Pukas, A. Transformacje Praktyk Mobilności Miejskiej. Ustugi i Wartości, Rutyny i Innowacje; Wydawnictwo Uniwersytetu Ekonomicznego we Wrocławiu: Wrocław, Poland, 2020.

25. Rail 2050 Vision Rail-The Backbone of Europe's Mobility, International Union of Railways (UIC). Available online: https: / / uic.org/IMG/pdf/122017_errac_rail_2050_vision.pdf (accessed on 16 April 2021).

26. The Impact of Emerging Technologies on the Transport System. Available online: https://www.europarl.europa.eu/RegData/ etudes/STUD/2020/652226/IPOL_STU(2020)652226_EN.pdf (accessed on 16 April 2021).

27. Iliashenko, O.; Iliashenko, V.; Lukyanchenko, E. Big Data in Transport Modelling and Planning. Transp. Res. Procedia 2021, 54, 900-908. Available online: https:/ / www.sciencedirect.com/science/article/pii/S2352146521003240 (accessed on 19 March 2021). [CrossRef]

28. Koleje Pasażerskie w Województwach-Dynamika Zmian, (Kwiecień 2017); Urząd Transportu Kolejowego: Warszawa, Poland, 2017. Available online: https://utk.gov.pl/pl/dokumenty-i-formularze/opracowania-urzedu-tran/12887,Koleje-pasazerskie-wwojewodztwach-dynamika-zmian.html (accessed on 20 February 2021). 
29. Drewnowski, A. Funkcjonowanie i rozwój regionalnych kolejowych przewozów pasażerskich w Polsce. Probl. Transp. i Logistyki 2019, 45. Available online: http://yadda.icm.edu.pl/yadda/element/bwmeta1.element.baztech-0a1ee418-9fdd-4834-a43d-9927 d827480a (accessed on 19 February 2021).

30. Bolobonov, D.; Frolov, A.; Borremans, A.; Schuur, P. Managing Public Transport Safety Using Digital Technologies. Transp. Res. Procedia 2021, 54, 862-870. Available online: https://www.sciencedirect.com/science/article/pii/S2352146521003197?via\% 3Dihub (accessed on 19 March 2021).

31. Brumercikova, E.; Bukova, B.; Nedeliakova, E. A Proposal for the Account-Based Ticketing Application in Passenger Transport in the Slovak Republic: A Case Study. Sustainability 2020, 12, 5491. [CrossRef]

32. Kos, B. E-płatności w publicznym transporcie zbiorowym. Ekon. Probl. Ustug 2018, 131, 97-105. Available online: https: //wnus.edu.pl/epu/pl/issue/983/article/15916/ (accessed on 19 March 2021). [CrossRef]

33. Kos, B.; Krawczyk, G.; Tomanek, R. Inkluzywna Mobilność w Metropoliach; Wydawnictwo Uniwersytetu Ekonomicznego w Katowicach: Katowice, Poland, 2020.

34. Rosa, G. Analysis of preferences of rail passengers in the context of sustainable development/ Sustainable economic development and advancing education excellence in the era of global pandemic. In Proceedings of the 36th International Business Information Management Association Conference (IBIMA), Granada, Spain, 4-5 November 2020; Soliman, K.S., Ed.; International Business Information Management Association: Granada, Spain, 2020.

35. Rosa, G. Preferences of rail transport passengers with regard to modern technologies/ Sustainable economic development and advancing education excellence in the era of global pandemic. In Proceedings of the 36th International Business Information Management Association Conference (IBIMA), Granada, Spain, 4-5 November 2020.

36. Badanie Satysfakcji Pasażerów Kolei. Available online: https://utk.gov.pl/pl/dokumenty-i-formularze/opracowania-urzedutran/16097,Badanie-satysfakcji-pasazerow-kolei.html (accessed on 19 March 2021).

37. Froidh, O.; Bystrom, C. Competition on the tracks-Passengers' response to deregulation of interregional rail services. Transp. Res. A Policy Pract. 2013, 56, 1-10. [CrossRef]

38. Tsafarakis, S.; Kokotas, T.; Pantouvakis, A. A multiple criteria approach for airline passenger satisfaction measurement and service quality improvement. J. Air Transp. Manag. 2018, 68, 61-75. [CrossRef]

39. Paha, J.; Rompf, D.; Warnecke, C. Customer choice patterns in passenger rail competition. Transp. Res. Part 2013, 50, 209-227. [CrossRef]

40. Hlavatý, J.; Ližbetin, J. Innovation in Rail Passenger Transport as a Basis for the Safety of Public Passenger Transport. Transp. Res. Procedia 2021, 54, 98-105. Available online: https://www.sciencedirect.com/science/article/pii/S2352146521001721 (accessed on 19 March 2021). [CrossRef]

41. Antonowicz, M.; Bogucka, K. Coworking-Nowy produkt dla pasażera kolei. Probl. Transp. i Logistyki 2019, 46, 7-18.

42. Mazzino, N.; Perez, X.; Meuser, U.; Santoro, R.; Brennan, M.; Schlaht, J.; Chéron, C.; Samson, H.; Dauby, L.; Furio, N.; et al. The Rail 2050 Vision-Rail the Backbone of Europe's Mobility; The European Rail Research Advisory Council: Paris, France, 2017.

43. Bocheński, T.; Wojtkiewicz, S. Regionalizacja kolei w Polsce i województwie zachodniopomorskim. Probl. Transp. i Logistyki 2019, 45, 7-18.

44. Krawiec, K.; Ćwiek, J. Analiza trendów w kolejowych przewozach pasażerskich PTiL. Probl. Transp. i Logistyki 2019, 45. Available online: www.wnus.edu.pl/ptil (accessed on 20 February 2021). [CrossRef]

45. Massel, A. Kolejowe przewozy regionalne i aglomeracyjne-Ewolucja oferty przewozowej w latach 1990-2017 i jej uwarunkowania infrastrukturalne oraz taborowe. Probl. Transp. I Logistyki 2019, 1, 75-86.

46. Mężyk, A. Regionalizacja kolejowych przewozów pasażerskich. Założenia i realizacja. Probl. Transp. i Logistyki 2019, 45, 87-95.

47. Szałucki, K. Spór o system finansowania rozwoju kolei aglomeracyjnej województwa pomorskiego. Probl. Transp. i Logistyki 2019, 1, 119-126.

48. Kotler, P.; Keller, K. Lane 2012, Marketing; Dom Wydawniczy Rebis: Poznań, Poland, 2012; pp. $136-142$.

49. Abramovic, B.; Sipus, D. Quality Assessment of Regional Railway Passenger Transport. In Sustainable Rail Transport; Marinov, N., Piip, J., Eds.; Springer: Berlin/Heidelberg, Germany, 2019; pp. 83-96.

50. Enoch, M.P.; Cross, R.; Potter, N.; Davidson, C.; Taylor, S.; Brown, R.; Huang, H.; Parsons, J.; Tucker, S.; Wynne, E.; et al. Future local passenger transport system scenarios and implications for policy and practice. Transp. Policy 2020, 90, 52-67. Available online: https://www.sciencedirect.com/science/article/pii/S0967070X19305189?via\%3Dihub (accessed on 19 March 2021). [CrossRef]

51. Rasouli, S.; Timmermans, H. Applications of theories and models of choice and decision-making under conditions of uncertainty in travel behavior research. Travel Behav. Soc. 2014, 1, 79-90. [CrossRef]

52. Badanie Pilotażowe Zachowań Komunikacyjnych Ludności w Polsce, Etap III-Raport Końcowy; Centrum Badań i Edukacji Statystycznej GUS: Jachranka, Poland, 2015.

53. Awad-Núñez, S.; Julio, R.; Gomez, J.; Moya-Gómez, B.; Sastre González, J. Post-COVID-19 travel behaviour patterns: Impact on the willingness to pay of users of public transport and shared mobility services in Spain. Eur. Transp. Res. Rev. 2021, 13, 1-18. [CrossRef]

54. Kothari, A.; Madireddy, M.; Sundararajan, R. Discovering patterns in traveler behaviour using segmentation. J. Revenue Pricing Manag. 2016, 15, 334-351. [CrossRef] 
55. Branda, F.; Marozzo, F.; Talia, D. Ticket Sales Prediction and Dynamic Pricing Strategies in Public Transport. Big Data Cogn. Comput. 2020, 4, 36. [CrossRef]

56. Sołtys, J. Małe Miasta z Funkcją Przemysłową w Aktywizacji Obszarów Peryferyjnych Północnej Polski. 2013. Available online: https:/ / www.ue.katowice.pl/fileadmin/_migrated/content_uploads/2_J.Soltys_Male_miasta_z_funkcja_przemyslowa. ...pdf (accessed on 14 April 2021).

57. 2018 Rail Transport. Report; UTK Warszawa. 2019. Available online: https://utk.gov.pl/pl/dokumenty-i-formularze/ opracowania-urzedu-tran/15276,Sprawozdanie-z-funkcjonowania-rynku-transportu-kolejowego-w-2018-r.html (accessed on 10 February 2021).

58. 2019 Rail Transport. Report; UTK Warszawa. 2020. Available online: file:// /C:/Users/User/Downloads/SPRAWOZDANIE_20 19_ver_2_s\%20(1).pdf (accessed on 10 February 2021).

59. GUS. Transport.—Wyniki Działalności; GUS: Warszawa, Poland, 2019.

60. Wykorzystanie i Potencjał Kolejowych Przewozów Pasażerskich w Polsce. 2017. Available online: https://utk.gov.pl/pl/ dokumenty-i-formularze/opracowania-urzedu-tran/12753, Wykorzystanie-i-potencjal-kolejowych-przewozow-pasazerskichw-Polsce.html (accessed on 10 February 2021).

61. Transport in the European Union Current Trends and Issues. 2019. Available online: https://ec.europa.eu/transport/sites/ transport/ files / 2019-transport-in-the-eu-current-trends-and-issues.pdf (accessed on 19 March 2021).

62. Engelhardt, J. Sektor Kolejowy w Polityce Transportowej Unii Europejskiej; Wydawnictwo Edu-Libri: Kraków, Poland, 2018. 